\title{
Short Communication: \\ Molecular characteristics and phylogenetic relationships of silurid catfishes (Kryptopterus, Ompok and Phalacronotus) from the Kampar River, Indonesia, based on the cytochrome bene
}

\author{
ROZA ELVYRA ${ }^{1, \bullet}$, DEDY DURYADI SOLIHIN ${ }^{2}$, RIDWAN AFFANDI $^{3}$, MUHAMMAD ZAIRIN JUNIOR ${ }^{4}$, \\ MEYLA SUHENDRA ${ }^{1}$ \\ ${ }^{1}$ Department of Biology, Faculty of Mathematics and Natural Science, Universitas Riau. Jl. HR. Soebrantas Km. 12.5, Panam, Pekanbaru 28293, Riau, \\ Indonesia. Tel.: +62-761-63273, `email: roza.elvyra@lecturer.unri.ac.id; roza.elvyra @gmail.com \\ ${ }^{2}$ Department of Biology, Faculty of Mathematics and Natural Science, Institut Pertanian Bogor. J1. Meranti, Darmaga, Bogor 16680, West Java, \\ Indonesia \\ ${ }^{3}$ Department of Fishery Resources, Faculty of Fisheries and Marine Science, Institut Pertanian Bogor. Jl. Rasamala, Darmaga, Bogor 16680, West Java, \\ Indonesia \\ ${ }^{4}$ Department of Aquaculture, Faculty of Fisheries and Marine Science, Institut Pertanian Bogor. Jl. Rasamala, Darmaga, Bogor 16680, West Java, \\ Indonesia
}

Manuscript received: 20 December 2019. Revision accepted: 11 July 2020.

\begin{abstract}
Elvyra R, Solihin DD, Affandi R, Junior MZ, Suhendra M. 2020. Short Communication: Molecular characteristics and phylogenetic relationships of silurid catfishes (Kryptopterus, Ompok, and Phalacronotus) from the Kampar River, Indonesia, based on the cytochrome $b$ gene. Biodiversitas 21: 3539-3546. The study of molecular characteristics and phylogenetic relationships among silurid catfishes (Kryptopterus, Ompok, and Phalacronotus) is very scarce. Existing data are mostly based on morphological characters. Genetic markers among Kryptopterus, Ompok, and Phalacronotus can be analyzed by exploring the nucleotide and amino acid sequences of the mitochondrial cytochrome $b$ gene region (906 base pairs). This study aims to identify molecular characteristics and phylogenetic relationships of silurid catfishes from the Kampar River based on the cytochrome b gene. This research examined 14 silurids of four species from three genera in the Kampar River of Indonesia. Molecular phylogenetic trees were constructed using the neighbor-joining method. This study revealed that three amino acid sites can be used as specific genetic markers for characterizing Kryptopterus limpok. They are E (glutamic acid) at site 123, V (valine) at site 155, and M (methionine) at site 156 . Two amino acid sites can be used as specific genetic markers of Ompok spp., A (alanine) at site 201 for $O$. hypophthalmus, and S (serine) at site 282 for $O$. eugeneiatus. Two amino acid sites, I (isoleucine) at site 197 and L (leucine) at site 284, can be used to identify Phalacronotus apogon from the Kampar River, Indonesia. The phylogram results based on genetic distance (p-distance) from nucleotide cytochrome $b$ sequences generally showed that intraspecies of K. limpok, O. eugeneiatus, O. hypophthalmus and P. apogon from the Kampar River formed relationship groups within each species supported by high bootstrap values. Additionally, based on genetic distance, K. limpok data from the Kampar River samples and GenBank formed one relationship group within species of $K$. limpok with a high bootstrap value. This study proves that cytochrome b gene can be used to identify molecular characteristics and phylogenetic relationships of $K$. limpok, O. eugeneiatus, O. hypophthalmus, and P. apogon from the Kampar River, Indonesia.
\end{abstract}

Keywords: Catfish, Cytochrome b, Indonesia, Kampar River

\section{INTRODUCTION}

Phalacronotus, Kryptopterus, and Ompok are freshwater catfish belonging to the family Siluridae in order of Siluriformes. The members of the silurid catfish genus Phalacronotus and Kryptopterus are small- to medium-sized fishes, whereas Ompok is medium-sized. This catfish lives in freshwaters of South and Southeast Asia (Ng 2003; Ng and Tan 2004). The genus Phalacronotus, Kryptopterus, and Ompok, as currently understood, are probably paraphyletic based on morphological characters (Bornbusch 1995). The nonmonophyly of the genus Kryptopterus comprises distinct clades ( $K$. bicirrhis, $K$. cryptopterus, $K$. limpok and $K$. schilbeides groups) ( $\mathrm{Ng}$ and Kotelat 2013), while the $K$. apogon and $K$. hexapterus groups are assigned to distinct genus (Phalacronotus and Micronema respectively; Ferraris 2007). The genus Ompok has also been acknowledged as a non-monophyletic group, that it is comprised of four clades (O. bimaculatus, O. leiacanthus, O. hypophthalmus, and O. eugeneiatus group) ( $\mathrm{Ng} \mathrm{2013).}$

Approaches for identification are mostly based on morphological characteristics ( $\mathrm{Ng}$ and Hadiaty 2009; $\mathrm{Ng}$ and Kottelat 2013; Sudasinghe and Meegaskumbura 2016; Batubara et al. 2018) because they are easier and not expensive. Yet, this approach has several boundaries or constraints. One of which is the body part of the object to be identified must be complete. Species morphological identification also has several limitations. For example, identification keys are often only suitable for certain stages of life or gender, so high expertise in taxonomy is needed (Hebert et al. 2003). At present, there is a new approach to 
determining species, called DNA barcodes, using a short piece of DNA from the genome of the organism (Hebert et al. 2003; Stoeckle 2003; Patwardhan et al. 2014). DNAbased studies allow taxonomists to identify specimens even if they are incompleted, such as body fragments (Ivanova et al. 2007), larval stages (Azmir et al. 2017), and cryptic species (Ayudhaya et al. 2017). The morphology and molecular data can be used in cooperation of complement each other to resolve the taxonomic complication.

Molecular technique with the mitochondrial cytochrome $b$ gene is often used in systematic and phylogenetic research at various fish taxonomic levels. Farias et al. (2001) investigated the utility of the cytochrome $b$ gene as a genetic marker for concluding phylogenetic relationships of taxonomic levels within fish of the family Cichlidae. The phylogenetic utility of the cytochrome $b$ gene has been studied at some taxonomic levels of fish taxa (e.g., Doadrio et al. 2002; Doadrio and Dominguez 2004; Peng et al. 2004; Hardman 2005; Ketmaier et al. 2004; Barat et al. 2012; Wilcox et al. 2004). Moreover, the cytochrome $\mathrm{b}$ gene has been used as a tool to differentiate various species of bullhead torrent catfish (Kartavtsev et al. 2007), European catfish (Vittas et al. 2010) and Anabantoidei fish (Degani 2013).

The cytochrome $b$ gene contains the position of codons that develop slowly and rapidly, as well as more intraspecific variations, especially in the third position of codons that can be used to identify stocks (Habib et al. 2011). Therefore, this gene has been used for a diversity of systematic questions (Malakar et al. 2013). In this study, the mitochondrial cytochrome $b$ gene region (906 base pairs) was used for genetic markers of 14 individuals from four species from three genera of silurid catfishes in the Kampar River, Indonesia. There are four species of catfishes from the genera Kryptopterus, Ompok, and Phalacronotus in the Kampar River: $K$. limpok, $O$. eugeneiatus, O. hypophthalmus, and P. apogon. Catfishes of these genera are consumed by humans and have a high economic value when prepared as smoked fish. The research on cytochrome $\mathrm{b}$ in Indonesia has been carried out on Chanos chanos (Adiputra et al. 2011), Puntius cf. binotatus (Karlina et al. 2016), Osphronemus goramy (Nugroho et al. 2019), Bagridae, Pangasiidae and Ariidae (Megarani et al. 2020). Research on the cytochrome b gene in silurid catfishes is very scarce in Indonesia; in fact, cytochrome $\mathrm{b}$ data for $O$. eugeneiatus and $O$. hypophthalmus have not been in GenBank until now (updated on December $9^{\text {th }}$ of 2019). Hence, the aim of this research is to explore the utility of the cytochrome $b$ gene as a genetic marker to identify molecular characteristics and phylogenetic relationships of $K$. limpok, O. eugeneiatus, $O$. hypophthalmus and P. apogon from Kampar River, Indonesia.

\section{MATERIALS AND METHODS}

\section{Sample collection and preparation}

A total of 14 individuals of silurids were used for analysis purposes. Four species, K. limpok (3 individuals), $O$. eugeneiatus (3 individuals), O. hypophthalmus (5 individuals), and $P$. apogon (3 individuals), were collected in the Kampar River ( $\left.0^{\circ} 15^{\prime} 57.2^{\prime \prime N} 101^{\circ} 42^{\prime} 32.5^{\prime \prime E}\right)$, Riau Province, Indonesia. Caudal muscle tissue was taken from each sample to DNA analysis. The samples were preserved in $96 \%$ ethanol before the DNA extraction process.

\section{DNA extraction and PCR amplification}

Total DNA was isolated by a standard proteinase $\mathrm{K}$ and phenol/chloroform extraction method (Sambrook et al. 1989). Fragments of the cytochrome b gene (1104 bp) were amplified via polymerase chain reaction (PCR) from each DNA sample. The specific primers CBKR1 5'CCCGAAAAACTCACCCCTTA3' and CBKR2 5'ATAGCCCGGTTAGAGGGTTT3' were designed as cytochrome b primers (Elvyra 2009).

The PCR reaction mixture contained $100 \mathrm{ng}$ of template DNA, $0.2 \mu \mathrm{M}$ of each primer, $1 \mathrm{x}$ reaction buffer, $0.15 \mathrm{mM}$ of $\mathrm{MgCl}_{2}, 0.2 \mathrm{mM} \mathrm{dNTPS}, 2.0$ units Taq DNA polymerase and pure water until $50 \mu \mathrm{L}$ total reaction. The amplification process was conducted as follows: an initial $94^{\circ} \mathrm{C}$ denaturation for $5 \mathrm{~min}, 35$ cycles of $94^{\circ} \mathrm{C}$ denaturation for $30 \mathrm{~s}, 51^{\circ} \mathrm{C}$ annealing for $45 \mathrm{~s}, 72^{\circ} \mathrm{C}$ extension for $1 \mathrm{~min}$, and a final $72^{\circ} \mathrm{C}$ extension for $5 \mathrm{~min}$ (Elvyra 2009). PCR products were electrophoresed for analysis on a $1.2 \%$ agarose gel. Nucleotide sequences of the cytochrome b gene were determined using purified PCR products. The same primers, i.e., CBKR1 and CBKR2, were used for sequencing. Strands were sequenced in both directions for each sample. Phenograms and alignments were visually checked and verified.

\section{Mitochondrial DNA data analysis}

Homologous nucleotide or amino acid sequences in the cytochrome $b$ gene of the mitochondrial DNA were obtained and then aligned (multiple alignments) in comparison with cytochrome b gene sequences of Kryptopterus, Ompok and Micronema species from GenBank data: $K$. minor (AY458895), K. limpok (DQ119431), O. bimaculatus (KJ646879), O. miostoma (DQ119435) and Micronema apogon (DQ119409). The cytochrome b gene sequence of Ictalurus punctatus (AB045119) from GenBank data was used as an outgroup for phylogenetic analysis.

Amino acids for coding followed the genetic code for vertebrate mitochondrial DNA. Analysis of genetic markers and relationships based on nucleotides and amino acid sequences were conducted using the MEGA program version 6.0 (Tamura et al. 2013) with the bootstrapped neighbor-joining method with 1000 replicates. All sequences were submitted to the National Center for Biotechnology Information (NCBI) with accession numbers of MH745411-MH745413 for K. limpok, MH793319MH793321 for O. eugeneiatus, MH793322-MH793326 for O. hypophthalmus and MH745414-MH745416 for P. apogon.

\section{RESULTS AND DISCUSSION}

Cytochrome $\mathrm{b}$ gene amplification using the forward primer CBKR1 and reverse primer CBKR2 produced a $1104 \mathrm{bp}$ cytochrome $\mathrm{b}$ gene fragment in all species of 
catfish. Based on the complete cytochrome $b$ gene sequence (1141 bp) of $K$. minor (GenBank, 2009, access code AY458895; Wilcox et al. 2004), which was used as a reference, this fragment is located from base 8 to 1111 . The DNA sequence from the multiple alignments of 906 nucleotides is located at position 115 to 1020 (for the whole 1141-bp reference based on the complete cytochrome $\mathrm{b}$ gene of $K$. minor from GenBank data).

The overall nucleotide composition of cytochrome $b$ was obtained (Table 1); on average, the nucleotide $\mathrm{C}$ is the most dominant $(32.1 \%)$, while the least frequent nucleotide is $\mathrm{G}(14.3 \%)$. Regarding codon positions, the most common nucleotide in the first codon position is $\mathrm{C}$ $(26.4 \%)$, while the least nucleotide in the first codon position is A $(23.5 \%)$. The most common nucleotide in the second codon position is $\mathrm{T}(41.1 \%)$, while the least nucleotide in the second codon position is $\mathrm{G}(13.3 \%)$. Finally, the most common nucleotide in the third codon position is $\mathrm{C}(44.5 \%)$, while the least nucleotide in the third codon position is $G(3.6 \%)$. In this study, low $G$ values found in the second and the third codon position. Results of this study have the lowest $G$ values in the nucleotide composition of the cytochrome $b$ gene. Low $G$ values are commonly found in the mitochondrial DNA of the Iberian Barbels fishes (Doadrio et al. 2002) and Glyptosternoid fishes (Peng et al. 2004). This lower $G$ value is also found in O. bimaculatus (Malakar et al. 2013). The pattern of differences between A, T, C, and G can show genetic signs and characteristics of a species (Afreixo et al. 2009).

It is also found that the greatest variation of the nucleotide composition was in the position of the third codon from codon triplets of the cytochrome $b$ gene. Doadrio and Perdices (2005); Ketmaier et al. (2004); Peng et al. (2004) also found the greatest variation at the third codon position of codon triplets on the whole cytochrome $b$ gene. This is because the first and the second positions have a low substitution rate, while the third position has a higher substitution value (Farias et al. 2001).

Overall, composition nucleotide showed a similar condition, which is $\mathrm{A}+\mathrm{T}$, was greater than $\mathrm{G}+\mathrm{C}$. The average $\mathrm{A}+\mathrm{T}$ nucleotide composition of $K$. limpok, Ompok spp. and P. apogon (53.5\%) was greater than the average $\mathrm{G}+\mathrm{C}$ nucleotide composition (46.5\%). The highest nucleotide $\mathrm{A}+\mathrm{T}$ composition was found in $K$. limpok (53.8\%), and the lowest nucleotide $\mathrm{A}+\mathrm{T}$ composition was found in O. hypophthalmus (52.0\%). A greater $\mathrm{A}+\mathrm{T}$ composition than $\mathrm{G}+\mathrm{C}$ composition was also found by Ketmaier et al. (2004) and Malakar et al. (2013). The nucleotide sequence pattern of cytochrome $b$ rich in $\mathrm{A}+\mathrm{T}$ nucleotide base composition was generally shown for taxa of fishes (Johns and Avise 1998).

Based on the 380 amino-acid references of the $K$. minor cytochrome $b$ gene (GenBank data, access code AY458895), 906 nucleotides were coded for 302 amino acids in the region from amino acid position 39 to 340. Amino acid sites can distinguish species of $K$. limpok (Table 2), P. apogon (Table 3), and Ompok spp. (Table 4) from the Kampar River. Intraspecies markers of $K$. limpok from the Kampar River can be characterized by specific amino acid sites. Three amino acid sites have a marker pattern specific to the species K. limpok; of these sites, i.e., $\mathrm{V}$ (valine) at site 155 and $\mathrm{M}$ (methionine) at site 156, are characterizing $K$. limpok from both the Kampar River and GenBank data. The amino acid at site 123 is E (glutamic acid), characterizing the population of $K$. limpok only from Kampar with the codon GAA.

Intraspecies markers of $P$. apogon from the Kampar River also can be characterized by specific amino acid sites. Species of $P$. apogon from Kampar river have two amino acid sites, i.e., sites 197 and 284 as a specific marker. Two amino acids are I (isoleucine) and L (leucine), which are coded by the codons of ATC and CTC (Table 3). These amino acids can be used as markers to distinguish $P$. apogon from other species.

Nucleotide sequences of cytochrome b gene of $O$. hypophthalmus and O. eugeneiatus are not found in the GenBank data. Therefore, data for O. hypophthalmus and $O$. eugeneiatus were obtained from this research. Intraspecies markers in the genus Ompok from the Kampar River can be characterized by specific amino acid sites. There are two amino acid sites that can be used as specific genetic markers for species in the genus Ompok from the Kampar River (Table 4). One amino acid site, i.e., S (serine) at site 282, has a pattern specific to O. eugeneiatus from the Kampar River with the codon TCC. Catfish of $O$. hypophthalmus can also be differentiated from other species. One amino acid, i.e., A (alanine) at site 201 can be used as a marker for O. hypophthalmus from the Kampar River with the codon GCA.

This research has been able to determine the genetic markers of K. limpok, P. apogon, and Ompok spp. This was not found before in Elvyra et al. (2009), which amplified the cytochrome $b$ gene using a universal primer only 373 $\mathrm{bp}$, with the results of multiple alignments of 159 nucleotides and translating 53 amino acids at sites 62-114 based on the reference of complete cytochrome $b$ gene.

A genetic distance matrix of the nucleotide sequences of $K$. limpok, Ompok spp. and P. apogon is shown in Table 5. The genetic distance between the nucleotide sequences of $K$. limpok from the Kampar River with that of $K$. limpok from GenBank data is 0.03 , while the genetic distance within the group of $K$. limpok from the Kampar River is 0.00-0.01. The genetic distance among the nucleotide sequences of $P$. apogon from the Kampar River is 0.000.01 .

The genetic distance based on the nucleotide sequence within the O. eugeneiatus group from the Kampar River is 0.00 . The genetic distance within O. hypophthalmus group is similar to that within $O$. eugeneiatus group from the Kampar River, which is 0.00 . The cytochrome $b$ gene can be used to analyze genetic distance and phylogenetic relationships of Kryptopterus, Ompok, and Phalacronotus. This was also found in research of Schizothorax and Schizopyge species in the subfamily of Schizothoracinae (Barat et al. 2012); also in strains of Osphronemus goramy (Nugroho et al. 2019). 
Table 1. Compositions of the four nucleotide bases from the partial cytochrome $b$ gene

\begin{tabular}{|c|c|c|c|c|c|c|c|c|c|c|c|c|c|c|c|c|c|c|}
\hline & $\mathbf{T}(\mathbf{U})$ & $\mathbf{C}$ & $\mathbf{A}$ & $\mathbf{G}$ & $A+T$ & G+C & T-1 & C-1 & A-1 & G-1 & T-2 & C-2 & A-2 & G-2 & T-3 & $\mathrm{C}-3$ & A-3 & G-3 \\
\hline [1] & 26.6 & 31.9 & 27.2 & 14.3 & 53.8 & 46.2 & 24.2 & 25.8 & 23.5 & 26.5 & 41.1 & 25.5 & 20.2 & 13.2 & 14.6 & 44.4 & 37.7 & 3.3 \\
\hline$[2]$ & 26.7 & 31.8 & 27.2 & 14.3 & 53.9 & 46.1 & 24.2 & 25.8 & 23.5 & 26.5 & 41.4 & 25.2 & 20.2 & 13.2 & 14.6 & 44.4 & 37.7 & 3.3 \\
\hline [3] & 26.6 & 32.0 & 27.0 & 14.3 & 53.6 & 46.4 & 24.2 & 26.2 & 23.2 & 26.5 & 41.4 & 25.2 & 19.9 & 13.6 & 14.2 & 44.7 & 38.1 & 3.0 \\
\hline $\mathbf{r}$ & 26.6 & 31.9 & 27.1 & 14.3 & 53.8 & 46.2 & 24.2 & 25.9 & 23.4 & 26.5 & 41.3 & 25.3 & 20.1 & 13.4 & 14.5 & 44.5 & 37.9 & 3.2 \\
\hline [4] & 27.3 & 31.8 & 26.2 & 14.8 & 53.4 & 46.6 & 24.5 & 26.2 & 23.5 & 25.8 & 41.1 & 25.5 & 20.2 & 13.2 & 16.2 & 43.7 & 34.8 & 5.3 \\
\hline [5] & 27.3 & 31.8 & 26.2 & 14.8 & 53.4 & 46.6 & 24.5 & 26.2 & 23.5 & 25.8 & 41.1 & 25.5 & 20.2 & 13.2 & 16.2 & 43.7 & 34.8 & 5.3 \\
\hline [6] & 27.4 & 31.8 & 26.0 & 14.8 & 53.4 & 46.6 & 24.8 & 26.2 & 23.2 & 25.8 & 41.1 & 25.5 & 20.2 & 13.2 & 16.2 & 43.7 & 34.8 & 5.3 \\
\hline $\mathbf{r}$ & 27.3 & 31.8 & 26.1 & 14.8 & 53.4 & 46.6 & 24.6 & 26.2 & 23.4 & 25.8 & 41.1 & 25.5 & 20.2 & 13.2 & 16.2 & 43.7 & 34.8 & 5.3 \\
\hline [7] & 23.8 & 34.5 & 28.1 & 13.5 & 52.0 & 48.0 & 22.8 & 27.8 & 23.5 & 25.8 & 40.7 & 25.8 & 20.2 & 13.2 & 7.9 & 50.0 & 40.7 & 1.3 \\
\hline$[8]$ & 24.0 & 34.5 & 28.0 & 13.5 & 52.0 & 48.0 & 22.8 & 27.8 & 23.5 & 25.8 & 40.7 & 25.8 & 20.2 & 13.2 & 8.3 & 50.0 & 40.4 & 1.3 \\
\hline [9] & 23.7 & 34.7 & 28.1 & 13.5 & 51.9 & 48.1 & 22.8 & 27.8 & 23.5 & 25.8 & 40.4 & 26.2 & 20.2 & 13.2 & 7.9 & 50.0 & 40.7 & 1.3 \\
\hline [10] & 23.8 & 34.5 & 28.1 & 13.5 & 52.0 & 48.0 & 22.8 & 27.8 & 23.5 & 25.8 & 40.7 & 25.8 & 20.2 & 13.2 & 7.9 & 50.0 & 40.7 & 1.3 \\
\hline$[11]$ & 23.8 & 34.5 & 28.1 & 13.5 & 52.0 & 48.0 & 22.8 & 27.8 & 23.5 & 25.8 & 40.7 & 25.8 & 20.2 & 13.2 & 7.9 & 50.0 & 40.7 & 1.3 \\
\hline $\mathbf{r}$ & 23.8 & 34.6 & 28.1 & 13.5 & 52.0 & 48.0 & 22.8 & 27.8 & 23.5 & 25.8 & 40.7 & 25.9 & 20.2 & 13.2 & 8.0 & 50.0 & 40.7 & 1.3 \\
\hline [12] & 25.6 & 32.2 & 26.9 & 15.2 & 52.5 & 47.5 & 23.8 & 26.5 & 23.2 & 26.5 & 41.4 & 24.8 & 20.2 & 13.6 & 11.6 & 45.4 & 37.4 & 5.6 \\
\hline [13] & 25.7 & 31.9 & 27.4 & 15.0 & 53.1 & 46.9 & 23.8 & 26.5 & 23.5 & 26.2 & 41.4 & 25.2 & 20.2 & 13.2 & 11.9 & 44.0 & 38.4 & 5.6 \\
\hline [14] & 25.7 & 32.2 & 27.0 & 15.0 & 52.8 & 47.2 & 23.8 & 26.5 & 23.5 & 26.2 & 41.4 & 25.2 & 20.2 & 13.2 & 11.9 & 45.0 & 37.4 & 5.6 \\
\hline $\mathbf{r}$ & 25.7 & 32.1 & 27.1 & 15.1 & 52.8 & 47.2 & 23.8 & 26.5 & 23.4 & 26.3 & 41.4 & 25.1 & 20.2 & 13.4 & 11.8 & 44.8 & 37.7 & 5.6 \\
\hline [15] & 29.1 & 29.0 & 27.4 & 14.5 & 56.5 & 43.5 & 25.8 & 24.2 & 23.8 & 26.2 & 40.7 & 25.8 & 20.2 & 13.2 & 20.9 & 37.1 & 38.1 & 4.0 \\
\hline$[16]$ & 26.6 & 31.8 & 26.8 & 14.8 & 53.4 & 46.6 & 23.5 & 26.2 & 23.2 & 27.2 & 41.4 & 25.2 & 20.2 & 13.2 & 14.9 & 44.0 & 37.1 & 4.0 \\
\hline [17] & 26.7 & 30.0 & 29.2 & 14.0 & 56.0 & 44.0 & 25.2 & 25.2 & 23.2 & 26.5 & 41.1 & 25.5 & 20.2 & 13.2 & 13.9 & 39.4 & 44.4 & 2.3 \\
\hline [18] & 27.7 & 29.7 & 28.6 & 14.0 & 56.3 & 43.7 & 24.8 & 25.8 & 23.8 & 25.5 & 41.1 & 25.5 & 20.2 & 13.2 & 17.2 & 37.7 & 41.7 & 3.3 \\
\hline [19] & 25.5 & 33.5 & 26.1 & 14.9 & 51.6 & 48.4 & 24.2 & 26.5 & 22.2 & 27.2 & 40.7 & 25.8 & 20.2 & 13.2 & 11.6 & 48.2 & 35.9 & 4.3 \\
\hline [20] & 29.4 & 28.1 & 28.0 & 14.5 & 57.4 & 42.6 & 23.8 & 25.8 & 25.8 & 24.5 & 42.4 & 24.5 & 19.5 & 13.6 & 21.9 & 34.1 & 38.7 & 5.3 \\
\hline $\mathbf{R}$ & 26.2 & 32.1 & 27.4 & 14.3 & 53.5 & 46.5 & 24.0 & 26.4 & 23.5 & 26.1 & 41.1 & 25.5 & 20.1 & 13.3 & 13.4 & 44.5 & 38.5 & 3.6 \\
\hline
\end{tabular}

Note: [1] K. limpok (Kampar 1); [2] K. limpok (Kampar 9); [3] K. limpok (Kampar 16); [4] O. eugeneiatus (Kampar 2); [5] O. eugeneiatus (Kampar 3); [6] O. eugeneiatus (Kampar 11); [7] O. hypophthalmus (Kampar 5); [8] O. hypophthalmus (Kampar 12); [9] O. hypophthalmus (Kampar 13); [10] O. hypophthalmus (Kampar 14); [11] O. hypophthalmus (Kampar 15); [12] P. apogon (Kampar 6); [13] P. apogon (Kampar 7); [14] P. apogon (Kampar 10); [15] K. minor (GB); [16] K. limpok (GB); [17] O. bimaculatus (GB); [18] O. miostoma (GB); [19] M. apogon (GB); [20] I. punctatus (GB); r. The average of each species from the Kampar River; R. Overall average. 
Table 2. Amino acid sites that are specific genetic markers in the partial cytochrome b gene (302 aa) of Kryptopterus limpok from the Kampar River with GenBank data for comparison

\begin{tabular}{|c|c|c|c|c|c|c|}
\hline \multirow{3}{*}{ Species } & \multicolumn{6}{|c|}{ Site positions } \\
\hline & \multicolumn{2}{|c|}{$\begin{array}{c}123 \\
(161)\end{array}$} & \multicolumn{2}{|c|}{$\begin{array}{c}155 \\
(193)\end{array}$} & \multicolumn{2}{|c|}{$\begin{array}{c}156 \\
(194)\end{array}$} \\
\hline & Codon triplet & Amino acid & Codon triplet & Amino acid & Codon triplet & Amino acid \\
\hline K. minor $(\mathrm{GB})$ & CAA & Q & GCC & A & ATC & I \\
\hline K. limpok (GB) & CAA & Q & GTA & $\mathrm{V}$ & ATA & $\mathrm{M}$ \\
\hline K. limpok (Kampar 1) & GAA & $\mathrm{E}$ & GTA & V & ATA & M \\
\hline K. limpok (Kampar 9) & GAA & $\mathrm{E}$ & GTA & V & ATA & M \\
\hline K. limpok (Kampar 16) & GAA & $\mathrm{E}$ & GTA & $\mathrm{V}$ & ATA & M \\
\hline
\end{tabular}

Note: Number in parentheses ( ) indicates site positions based on complete cytochrome b gene of Kryptopterus minor from GenBank data (GB); Q (glutamine); E (glutamic Acid); A (alanine); V (valine); I (isoleucine); M (methionine)

Table 3. Amino acid sites that are specific genetic markers in the partial cytochrome b gene (302 aa) of Phalacronotus apogon from the Kampar River with GenBank data for comparison

\begin{tabular}{|c|c|c|c|c|}
\hline \multirow{3}{*}{ Species } & \multicolumn{4}{|c|}{ Site positions } \\
\hline & \multicolumn{2}{|c|}{$\begin{array}{c}197 \\
(235)\end{array}$} & \multicolumn{2}{|c|}{$\begin{array}{c}284 \\
(322)\end{array}$} \\
\hline & Codon triplet & Amino acid & Codon triplet & Amino acid \\
\hline K. minor $(\mathrm{GB})$ & CTC & $\mathrm{L}$ & TTC & $\mathrm{F}$ \\
\hline M. apogon (GB) & CTC & $\mathrm{L}$ & TTC & $\mathrm{F}$ \\
\hline P. apogon (Kampar 6) & ATC & I & CTC & $\mathrm{L}$ \\
\hline P. apogon (Kampar 7) & ATC & I & CTC & $\mathrm{L}$ \\
\hline P. apogon (Kampar 10) & ATC & I & CTC & $\mathrm{L}$ \\
\hline
\end{tabular}

Note: Number in parentheses ( ) indicate site positions based on complete cytochrome b gene of Kryptopterus minor from GenBank data (GB); L (leucine); I (isoleucine); F (phenylalanine)

Table 4. Amino acid sites that are specific genetic markers in the partial cytochrome b gene (302 aa) of Ompok spp. from the Kampar River with GenBank data for comparison

\begin{tabular}{|c|c|c|c|c|}
\hline \multirow{3}{*}{ Species } & \multicolumn{4}{|c|}{ Site positions } \\
\hline & \multicolumn{2}{|c|}{$\begin{array}{c}201 \\
(239)\end{array}$} & \multicolumn{2}{|c|}{$\begin{array}{c}282 \\
(320)\end{array}$} \\
\hline & Codon triplet & Amino acid & Codon triplet & Amino acid \\
\hline O. bimaculatus (GB) & $\mathrm{ACA}$ & $\mathrm{T}$ & GCC & A \\
\hline O. miostoma $(\mathrm{GB})$ & $\mathrm{ACA}$ & $\mathrm{T}$ & GCC & A \\
\hline O. eugeneiatus (Kampar 2) & $\mathrm{ACA}$ & $\mathrm{T}$ & TCC & $\mathrm{S}$ \\
\hline O. eugeneiatus (Kampar 3) & $\mathrm{ACA}$ & $\mathrm{T}$ & TCC & $\mathrm{S}$ \\
\hline O. eugeneiatus (Kampar 11) & $\mathrm{ACA}$ & $\mathrm{T}$ & $\underline{\bar{T}} \mathrm{CC}$ & $\mathrm{S}$ \\
\hline O. hypophthalmus (Kampar 5) & $\underline{\mathrm{GCA}}$ & A & $\overline{\mathrm{GCC}}$ & A \\
\hline O. hypophthalmus (Kampar 12) & $\underline{\overline{\mathrm{G}}} \mathrm{CA}$ & A & GCC & A \\
\hline O. hypophthalmus (Kampar 13) & $\underline{\overline{\mathrm{G}}} \mathrm{CA}$ & A & GCC & A \\
\hline O. hypophthalmus (Kampar 14) & $\overline{\mathrm{G}} \mathrm{CA}$ & A & GCC & A \\
\hline O. hypophthalmus (Kampar 15) & $\underline{\overline{\mathrm{G}}} \mathrm{CA}$ & A & GCC & $\mathrm{A}$ \\
\hline
\end{tabular}

Note: Number in parentheses ( ) indicates site positions based on complete cytochrome b gene of Kryptopterus minor from GenBank data (GB); T (threonine); A (alanine); S (serine) 
Table 5. Matrix of genetic distances (p-distance) based on the nucleotide bases in the partial cytochrome $b$ gene of K. limpok, Ompok spp. and P. apogon from the Kampar River with GenBank data for comparison

\begin{tabular}{|c|c|c|c|c|c|c|c|c|c|c|c|c|c|c|c|c|c|c|c|c|}
\hline & [1] & {$[2]$} & [3] & [4] & [5] & {$[6]$} & [7] & {$[8]$} & [9] & [10] & [11] & [12] & [13] & [14] & [15] & [16] & {$[17]$} & [18] & [19] & [20] \\
\hline [1] & - & & & & & & & & & & & & & & & & & & & \\
\hline [2] & 0.15 & - & & & & & & & & & & & & & & & & & & \\
\hline [3] & 0.15 & 0.03 & - & & & & & & & & & & & & & & & & & \\
\hline [4] & 0.15 & 0.03 & 0.00 & - & & & & & & & & & & & & & & & & \\
\hline [5] & 0.15 & 0.03 & 0.01 & 0.00 & - & & & & & & & & & & & & & & & \\
\hline [6] & 0.16 & 0.16 & 0.15 & 0.15 & 0.15 & - & & & & & & & & & & & & & & \\
\hline [7] & 0.16 & 0.15 & 0.15 & 0.15 & 0.15 & 0.13 & - & & & & & & & & & & & & & \\
\hline [8] & 0.16 & 0.12 & 0.12 & 0.12 & 0.12 & 0.16 & 0.16 & - & & & & & & & & & & & & \\
\hline [9] & 0.16 & 0.12 & 0.12 & 0.12 & 0.12 & 0.16 & 0.16 & 0.00 & - & & & & & & & & & & & \\
\hline$[10]$ & 0.15 & 0.12 & 0.12 & 0.12 & 0.12 & 0.15 & 0.16 & 0.00 & 0.00 & - & & & & & & & & & & \\
\hline [11] & 0.14 & 0.11 & 0.11 & 0.11 & 0.11 & 0.13 & 0.15 & 0.13 & 0.13 & 0.12 & - & & & & & & & & & \\
\hline$[12]$ & 0.14 & 0.11 & 0.11 & 0.11 & 0.11 & 0.13 & 0.15 & 0.13 & 0.13 & 0.12 & 0.00 & - & & & & & & & & \\
\hline [13] & 0.14 & 0.11 & 0.11 & 0.11 & 0.11 & 0.13 & 0.15 & 0.13 & 0.13 & 0.12 & 0.00 & 0.00 & - & & & & & & & \\
\hline [14] & 0.14 & 0.11 & 0.11 & 0.11 & 0.11 & 0.13 & 0.15 & 0.13 & 0.13 & 0.12 & 0.00 & 0.00 & 0.00 & - & & & & & & \\
\hline [15] & 0.14 & 0.11 & 0.11 & 0.11 & 0.11 & 0.13 & 0.15 & 0.13 & 0.13 & 0.12 & 0.00 & 0.00 & 0.00 & 0.00 & - & & & & & \\
\hline [16] & 0.17 & 0.12 & 0.12 & 0.12 & 0.12 & 0.14 & 0.16 & 0.14 & 0.14 & 0.14 & 0.10 & 0.11 & 0.11 & 0.10 & 0.10 & - & & & & \\
\hline [17] & 0.16 & 0.12 & 0.12 & 0.12 & 0.12 & 0.15 & 0.17 & 0.13 & 0.13 & 0.13 & 0.11 & 0.11 & 0.11 & 0.11 & 0.11 & 0.12 & - & & & \\
\hline$[18]$ & 0.16 & 0.11 & 0.11 & 0.12 & 0.12 & 0.15 & 0.17 & 0.13 & 0.13 & 0.13 & 0.11 & 0.11 & 0.11 & 0.11 & 0.11 & 0.12 & 0.01 & - & & \\
\hline [19] & 0.16 & 0.11 & 0.11 & 0.12 & 0.12 & 0.15 & 0.17 & 0.13 & 0.13 & 0.13 & 0.11 & 0.11 & 0.11 & 0.11 & 0.11 & 0.11 & 0.00 & 0.00 & - & \\
\hline$[20]$ & 0.19 & 0.19 & 0.20 & 0.20 & 0.20 & 0.18 & 0.19 & 0.21 & 0.21 & 0.21 & 0.18 & 0.19 & 0.19 & 0.18 & 0.18 & 0.20 & 0.21 & 0.21 & 0.21 & - \\
\hline
\end{tabular}

Note: [1] K. minor (GB); [2] K. limpok (GB); [3] K. limpok (Kampar 1); [4] K. limpok (Kampar 9); [5] K. limpok (Kampar 16); [6] O. bimaculatus (GB); [7] O. miostoma (GB); [8] O. eugeneiatus (Kampar 2); [9] O. eugeneiatus (Kampar 3); [10] O. eugeneiatus (Kampar 11); [11] O. hypophthalmus (Kampar 5); [12] O. hypophthalmus (Kampar 12); [13] O. hypophthalmus (Kampar 13); [14] O. hypophthalmus (Kampar 14); [15] O. hypophthalmus (Kampar 15); [16] M. apogon (GB); [17] P. apogon (Kampar 6); [18] P. apogon (Kampar 7); [19] P. apogon (Kampar 10); [20] I. punctatus (GB). 


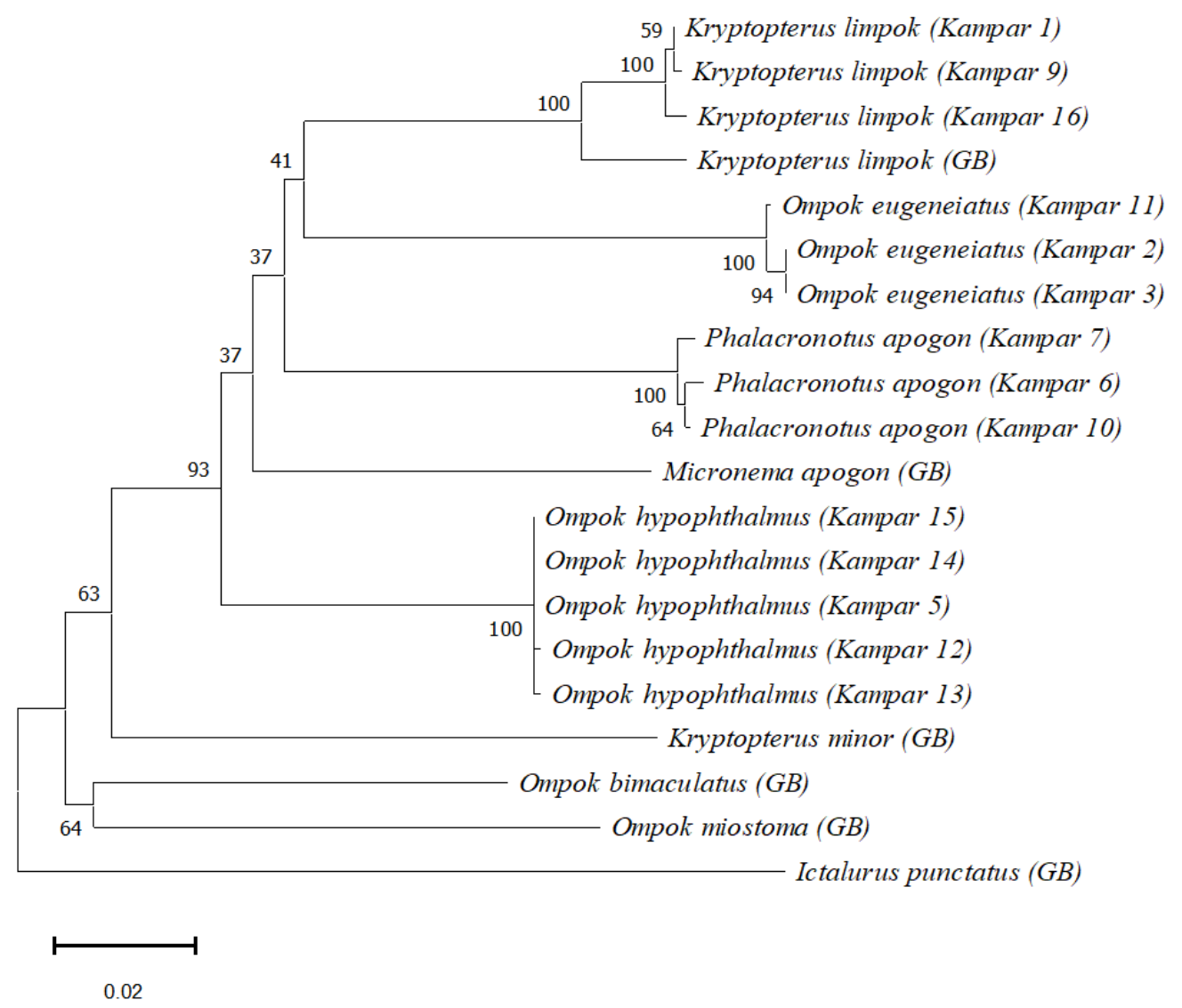

Figure 1. Phylogram using bootstrapped Neighbour-Joining method with 1000 replicates based on 906 cytochrome b gene nucleotide of Kryptopterus limpok, Ompok spp. and Phalacronotus apogon

A reconstruction of phylogenetic relationships of Kryptopterus, Ompok and Phalacronotus based on the genetic distances of nucleotide sequences is shown in Fig. 1. The phylogram results based on the cytochrome b nucleotide sequence showed that intraspecies of K. limpok, O. eugeneiatus, $O$. hypophthalmus and $P$. apogon from the Kampar River have relationship groups supported by a bootstrap value of $100 \%$. Catfish of $K$. limpok from the Kampar River and K. limpok from GenBank data formed a group with $100 \%$ bootstrap value.

The results of genetic distance (p-distance) based phylogram from nucleotide cytochrome $\mathrm{b}$ sequences generally showed that intraspecies samples of $K$. limpok, $O$. eugeneiatus, $O$. hypophthalmus and $P$. apogon from the Kampar River formed relationship groups within each species supported by high bootstrap values. Based on genetic distances from nucleotide sequences, $K$. limpok from the Kampar River formed a relationship group with $K$. limpok from GenBank data with high bootstrap values. This phylogenetic relationship is caused by a small value of genetic distance within the intraspecies of $K$. limpok, $O$. eugeneiatus, $O$. hypophthalmus, and $P$. apogon. The relationship of the groups of $K$. limpok, O. eugeneiatus, $O$. hypophthalmus, and $P$. apogon forms a large group because they are together in one family, namely Siluridae, which separates from the outgroup of I. punctatus from the family of Ictaluridae, but all belong to the same order of Siluriformes. This study supports the utility of the cytochrome $\mathrm{b}$ gene in phylogenetic relationships between Kryptopterus, Ompok, and Phalacronotus. This is in accordance with the results of molecular phylogenetic research that has been carried out on various species in the genus Puntius (Pallavi et al. 2012), Pangasiidae and Schilbidae (Karinthanyakit and Jondeung 2012) and also catfish species in the family of Bagridae, Pangasiidae, and Ariidae (Megarani et al. 2020).

The cytochrome $b$ gene is suitable as a marker from the intraspecies to the family levels and it has been shown to be useful for classifying relationships in a variety of fish. Based on codon position, cytochrome $b$ gene has conserved and varied regions. Conserved regions can be used as a genetic marker to accurately identify the genetic originality of a species and also as a genetic marker to determine the origin of a species. In contrast, varied regions can be used to determine phylogenetic relationships. This research has successfully identified the grouping of catfish species molecularly.

This work is a preliminary study of the molecular data of catfishes in the Kampar River, Indonesia. It can be concluded that the validity of the use of cytochrome $b$ as a 
genetic marker supports the species identification of catfish. The cytochrome $b$ gene can be used as a genetic marker to identify molecular characteristics and phylogenetic relationships of $K$. limpok, O. eugeneiatus, $O$. hypophthalmus, and $P$. apogon. This research provides an important contribution to enhance the database of silurid catfishes of $K$. limpok, O. eugeneiatus, O. hypophthalmus and $P$. apogon from the Kampar River, Indonesia.

\section{REFERENCES}

Adiputra YT, Hsu TH, Gwo JC. 2011. Genetic relationship of milkfish (Chanos chanos) from Indonesia, the Philippines and Taiwan using mitochondrial cytochrome b sequences. J Appl Ichthyol 27: 11001103.

Afreixo V, Bastos CAC, Pinho AJ, Garcia SP, Ferreira PJSG. 2009. Genome analysis with inter-nucleotide distances. Bioinformatics 25 (23): 3064-3070

Ayudhaya PTN, Muangmai N, Banjongsat N, Singchat W, Janekitkarn S, Peyachoknagul S, Srikulnath K. 2017. Unveiling cryptic diversity of the anemonefish genera Amphiprion and Premnas (Perciformes: Pomacentridae) in Thailand with mitochondrial DNA Barcodes. Agric Nat Resour 51: 198-205

Azmir IA, Esa Y, Amin SMN, Md Yasin IS, Md Yusof FZ. 2017. Identification of larval fish in mangrove areas of Peninsular Malaysia using morphology and DNA barcoding methods. J Appl Ichthyol 00: 1-9. DOI: 10.1111/jai.13425.

Barat K, Ali S, Sati J, Sivaraman GK. 2012. Phylogenetic analysis of fishes of the subfamily Schizothoracinae (Teleostei: Cyprinidae) from Indian Himalayas using Cytochrome b gene. Indian J Fish 59: 43-47.

Batubara AS, Muchlisin ZA, Efizon D, Elvyra R, Fadli N, Irham M. 2018. Morphometric variations of the genus Barbonymus (Pisces, Cyprinidae) harvested from Aceh Waters, Indonesia. Fish Aquat Life 26: 231-237.

Bornbusch A. 1995. Phylogenetic relationships within the Eurasian catfish family (Pisces: Siluriformes), with comments on generic validities and biogeography. Zool J Linn Soc 115: 1-46.

Degani G. 2013. Mitochondrial DNA sequence Analysis in Anabantoidei fish. Adv Biol Chem 3: 347-355.

Doadrio I, Carmona JA, Machordom A. 2002. Haplotype diversity and phylogenetic relationships among the Iberian Barbels (Barbus, Cyprinidae) Reveal Two Evolutionary Lineages. J Hered 93: 140-147.

Doadrio I, Dominguez O. 2004. Phylogenetic relationships within the fish family Goodeidae based on cytochrome $b$ sequence data. Mol Phylogenet Evol 31: 416-430.

Doadrio I, Perdices A. 2005. Phylogenetic relationships among the IberoAfrican Cobitids (Cobitis, Cobitidae) based on cytochrome b sequence data. Mol Phylogenet Evol 37: 484-493.

Elvyra, R. 2009. Kajian keragaman genetik dan biologi reproduksi ikan lais di Sungai Kampar Riau. [Dissertation]. Institut Pertanian Bogor, Bogor. [Indonesian]

Elvyra R, Solihin DD, Affandi R, Junior Z, Yus Y. 2009. Keanekaragaman genetika dan hubungan kekerabatan Kryptopterus limpok dan Kryptopterus apogon dari Sungai Kampar dan Sungai Indragiri Riau berdasarkan gen sitokrom b. Jurnal Ilmu-ilmu Perairan dan Perikanan Indonesia 16: 55-61. [Indonesian]

Farias IP, Orti G, Sampaio I, Schneider H, Meyer A. 2001. The cytochrome b gene as a phylogenetic marker: the limits of resolution for analyzing relationships among Cichlid fishes. Mol Phylogenet Evol 53: 89-103.

Ferraris CJ. 2007. Checklist of catfishes, recent and fossil (Osteichthyes, Siluriformes) and catalogue of siluriform primary types. Zootaxa 1418: 1-628.

Habib M, Lakra WS, Mohindra V, Khare P, Barman AS, Singh A, Lal KK, Punia P, Khan AA. 2011. Evaluation of cytochrome b mtDNA sequences in genetic diversity studies of Channa marulius (Channidae: Perciformes). Mol Biol Rep 38: 841-846.

Hardman M. 2005. The phylogenetic relationships among nondiplomystid catfishes as inferred from mitochondrial cytochrome b sequences; the search for the Ictalurid sister taxon (Otophysi: Siluriformes). Mol Phylogenet Evol 37: 700-720.

Hebert PDN, Cywinska A, Ball SL, Waard JRD. 2003.Biological identifications through DNA barcodes. Proc R Soc Lond B 270: 313 321.

Ivanova NV, Zemlak TS, Hanner RH, Hebert PD. 2007. Universal primer cocktails for fish DNA barcoding. Mol Ecol Notes 7 (4): 544-548.

Johns GC, Avise JC. 1998. A comparative summary of genetic distances in the Vertebrates from the mitochondrial cytochrome $b$ gene. Mol Biol Evol 15 (11): 1481-1490.

Karinthanyakit W, Jondeung A. 2012. Molecular phylogenetic relationships of Pangasiid and Schilbid catfishes in Thailand. J Fish Biol 80: 2549-2570.

Karlina W, Roesma DI, Tjong DH. 2016. Phylogenetic study of Puntius cf. binotatus fish from Gunung Tujuh Lake in Sumatera based on cytochrome b gene. J Entomol Zool Stud 4 (2): 538-540.

Kartavtsev YP, Jung S, Lee Y, Byeon H, Lee J. 2007. Complete mitochondrial genome of the bullhead torrent catfish, Liobagrus obesus (Siluriformes, Amblycipididae): Genome description and phylogenetic considerations inferred from the Cyt b and 16S rRNA genes. Gene 396: 13-27.

Ketmaier V, Bianco PG, Cobolli M, Krivokapic M, Caniglia R, De Matthaeis E. 2004. Molecular phylogeny of two lineages of Leuciscinae Cyprinids (Telestes and Scardinius) from the PeriMediterranean area based on cytochrome-b data. Mol Phylogenet Evol 32: 1061-1071.

Malakar AK, Lakra WS, Goswami M, Mishra RM. 2013.Genetic differentiation of Ompok bimaculatus (Teleostei: Siluridae) population based on mtDNA cytochrome b gene. Mitochondrial DNA 24 (2): 145-150

Megarani DV, Nugroho HA, Andarini ZP, Surbakti YDRBR, Widayanti R. 2020. Genetic characterization and phylogenetic study of Indonesian indigenous catfish based on mitochondrial cytochrome $\mathrm{b}$ gene. Vet World 13 (1): 96-103.

$\mathrm{Ng}$ HH. 2003. Kryptopterus geminus, a new species of Silurid catfish (Teleostei: Siluridae) from mainland Southeast Asia. Zootaxa 305: 111.

Ng HH, Hadiaty RK. 2009. Ompok brevirictus, a new catfish (Teleostei: Siluridae) from Sumatra. Zootaxa 2232: 50-60.

$\mathrm{Ng}$ HH. 2013. Ompok karunkodu, a new catfish (Teleostei: Siluridae) from Southern India. Zootaxa 3694 (2): 161-166.

$\mathrm{Ng} \mathrm{HH}$, Kottelat M. 2013. After eighty years of misidentification, a name for the glass catfish (Teleostei: Siluridae). Zootaxa 3630 (2): 308-316.

$\mathrm{Ng} \mathrm{HH}$, Tan HH. 2004. Ompok platyrhynchus a new Silurid catfish (Teleostei: Siluridae) from Borneo. Zootaxa 580: 1-11.

Nugroho E, Azrita, Syandri H, Dewi RRSPS. 2019 DNA barcoding of giant gourami (Osphronemus goramy) from West Sumatra, Indonesia. AACL Bioflux 12 (4): 1074-1079.

Pallavi, Goswami M, Nautiyal P, Malakar AK, Nagpure NS. 2012. Genetic divergence and molecular phylogenetics of Puntius spp. based on the mitochondrial cytochrome $b$ gene. Mitochondrial DNA 23(6): 477-483

Patwardhan A, Ray S, Roy A. 2014. Molecular markers in phylogenetic studies-A Review. J Phylogenet Evol Biol 2 (2): 1-9.

Peng Z, He S, Zhang Y. 2004. Phylogenetic relationships of Glyptosternoid fishes (Siluriformes: Sisoridae) inferred from mitochondrial cytochrome $b$ gene sequences. Mol Phylogenet Evol 31: 979-987.

Sambrook J, Fritsch EF, Maniatis T. 1989. Molecular cloning: a laboratory manual. In: Harbor CS (eds). Cold Spring Harbor Laboratory, New York.

Stoeckle M. 2003. Taxonomy, DNA, and the bar code of life. BioScience 53 (9): 796-797.

Sudasinghe H, Meegaskumbura, M. 2016. Ompok argestes, a new species of Silurid catfish endemic to Srilanka (Teleostei: Siluridae). Zootaxa 4158 (2): 261-271.

Tamura K, Stecher G, Peterson D, Filipski A, Kumar S. 2013. MEGA 6: Molecular Evolutionary Genetics Analysis Version 6.0. Mol Biol Evol 30 (12): 2725-2729.

Vittas S, Drosopoulou E, Kappas IN, Pantzartzi CG, Scouras Z. 2010. The mitochondrial genome of the European catfish Silurus glanis (Siluriformes, Siluridae). J Biol Res Thessaloniki 15: 25 - 35.

Wilcox TP, Garcia de Leon FJ, Hendrickson DA, Hillis DM. 2004. Convergence among cave catfishes: long-branch attraction and a Bayesian relative rates test. Mol Phylogenet Evol 31: 1101-1113. 